E-JURNAL EKONOMI DAN BISNIS UNIVERSITAS UDAYANA
Available online at https://ojs.unud.ac.id/index.php/EEB/index
Vol. 10 No. 7, July 2021, pages: 602-611
e-ISSN: 2337-3067

\title{
ANALISIS PERBANDINGAN RETURN ON ASSET DAN ECONOMIC VALUE $A D D E D$ PADA BANK KONVENSIONAL DAN BANK SYARIAH
}

\author{
Delia Arsita ${ }^{1}$ Nana Diana ${ }^{2}$
}

Article history:

Submitted: 23 Januari 2021

Revised: 11 Februari 2021

Accepted: 11 April 2021

\section{Keywords:}

Banks;

Financial Performance;

$R O A$;

EVA;

\section{Abstract}

Business competition in the banking world is getting tighter, this is what requires banks to maintain their financial performance. The study aims to compare the financial performance using the measurement of Return On Asset(ROA) and Economic Value Added(EVA) in Conventional Banks and Islamic Banks period 2015-2019. The data analysis technique used is comparative analysis and processed by using software SPSS 21, while data used are secondary data with quantitative data and sampling method that is purposive sampling. The results of this study indicate that there is a significant difference in the assessment of financial performance by measuring ROA and EVA in Conventional Banks and Islamic Banks. The financial performance of Islamic Banks is considered to be better based on ROA and EVA measurement. Overall, the measurement of EVA is considered better because this measurement can reflect the true value of the company by taking into account the risk of the bank that includes the cost of capital. Future research is suggested to add bank data samples, expand the research period, and also to add other measurements to get more accurate results.

Abstrak
Persaingan bisnis di dunia perbankan semakin ketat, hal ini lah
yang mengharuskan bank untuk mempertahankan kinerja keuangan nya.
Tujuan dari penelitian ini adalah untuk membandingkan kinerja keuangan
dengan menggunakan pengukuran Return On Asset (ROA) dan Economic
Value Added (EVA) pada bank umum konvensional dan bank umum
syariah selama periode 2015 - 2019 . Teknik analisis data yang di gunakan
adalah analisis komparatif dan diolah menggunakan software SPSS21,
sedangkan data yang di gunakan adalah data sekunder dengan jenis data
kuantitatif dan metode pengambilan sampel yaitu purposive sampling. Hasil
dari penelitian ini menunjukan bahwa ada nya perbedaan yang signifikan
dalam penilaian kinerja keuangan bank dengan pengukuran ROA dan EVA
pada bank konvensional dan bank syariah. Kinerja keuangan bank syariah
di nilai lebih baik berdasarkan pengukuran ROA dan EVA. Secara
keseluruhan pengukuran EVA di nilai lebih baik karena pengukuran ini
dapat mencerminkan nilai perusahaan yang sesungguhnya dengan
memperhitungkan resiko bank yang mengikutsertakan biaya modal di
dalamnya. Penelitian selanjutnya di sarankan untuk menambahkan sampel
data bank, memperluas periode penelitian dan juga menambahkan
pengukuran lainnya agar bisa mendapatkan hasil yang lebih akurat.

Kata Kunci:

Bank;

Kinerja Keuangan;

ROA;

EVA;

\section{Koresponding:}

Universitas Singaperbangsa

Karawang, Jawabarat,

Indonesia

Email:

deliaarsita10@gmail.com
Universitas Singaperbangsa Karawang, Jawabarat, Indonesia 2

Email: nanadiana.ekonomi@gmail.com 


\section{PENDAHULUAN}

Bank merupakan lembaga keuangan yang bergerak dibidang jasa yang dimana bank ini melakukan aktivitasnya yaitu untuk menghimpun dana dari masyarakat lalu menyalurkannya kepada yang membutuhkan pinjaman dana dan juga memberikan pelayanan jasa kepada pihak ketiga. Sedangkan perbankan adalah segala sesuatu yang berhubungan dengan bank beserta kegiatan yang berada didalamnya. Bank memiliki peranan yang sangat penting karena hampir semua sektor usaha menjadikan bank sebagai mitra kerja dalam pengembangan usahanya. (Ismail, 2014)

Pada tahun 2018 perang dagang terjadi antara Amerika Serikat dan China, kedua negara tersebut saling memberlakukan kebijakan terhadap perlindungan dagang yang mempengaruhi pertumbuhan perekonomian global. Negara yang bergantung pada ekspor-impor akan sangat rentan terkena dampaknya, salah satunya yaitu Negara Indonesia. Pada dunia perbankan kenaikan tarif bea masuk impor akan berdampak pada banyaknya dana asing yang keluar dari Indonesia, hal inilah yang akan menyebabkan suku bunga Surat Berharga Negara (SBN) menjadi naik. Ketika suku bunga SBN naik maka akan banyak peralihan pemilik dana membeli SBN daripada membeli ke bank dan yang harus dilakukan bank adalah mengurangi margin keuntungan dengan cara menaikan suku bunga deposito agar bank tersebut bisa bertahan dalam kompetisi bisnis ini. (www.cnbcindonesia.com)

Perkembangan bank bergerak beriringan dengan pertumbuhan perekonomian, jika terjadi ketidakstabilan dalam perkembangan bank maka hal tersebut akan mempengaruhi pertumbuhan perekonomian. Perang dagang antara Amerika Serikat dengan China ini bisa menyebabkan terjadinya ketidakstabilan dan mengganggu kesejahteraan didalam dunia perbankan yang selanjutnya akan mempengaruhi pertumbuhan perekonomian di Indonesia.

Sistem perbankan di Indonesia menggunakan Sistem Perbankan Ganda (Dual Banking System) yang dimana bank boleh melakukan kegiatan usahanya secara konvensional dan juga secara syariah. Bank konvensional dalam menjalankan kegiatannya berdasarkan prinsip umum yang menghasilkan keuntungan melalui sistem bunga tertentu dan tidak melanggar hukum yang berlaku, sedangkan bank syariah dalam menjalankan kegiatannya berdasarkan prinsip syariah yang menghasilkan keuntungan melalui sistem bagi hasil dan tidak melanggar hukum islam.

Pada bulan Desember tahun 2019 kedua jenis bank tersebut mengalami perkembangan yang cukup signifikan. Bank konvensional mengalami penurunan pada jumlah Bank Umum Konvensional nya menjadi 110, menurunnya jumlah Bank Pengkreditan Rakyat menjadi 1.545 dan meningkatnya total aset dari keduanya menjadi sebesar Rp. 8.712.597 miliar. Sedangkan bank syariah mengalami peningkatan pada jumlah Bank Umum Syariah nya menjadi 14, menurunnya jumlah Bank Umum Konvensional yang memiliki Unit Usaha Syariah menjadi 20, menurunnya jumlah Bank Pembiayaan Rakyat Syariah menjadi 164 dan meningkatnya total aset dari ketiganya menjadi sebesar Rp. 538.322 miliar. (www.ojk.go.id)

Dari tahun ketahun persaingan bisnis di Indonesia itu sangat ketat, hal inilah yang mengharuskan bank tersebut bisa memberikan inovasi-inovasi baru dan bisa mempertahankan kinerja yang baik agar bisa bersaing. Menurut (Septiyaningrum, 2018) Kinerja keuangan bank adalah suatu gambaran yang menunjukan bagaimana kondisi keuangan di periode tertentu, terutama yang berhubungan dengan kegiatan bank seperti penghimpunan serta penyaluran dana. Atau bisa disebut juga sebagai kemampuan perusahaan dalam menjalankan tugasnya untuk mencapai tujuan perusahaan tersebut. Hal ini dapat dikatakan baik apabila perusahaan tersebut bisa mencapai tujuannya dengan baik.

Baik buruknya kinerja bank bisa diukur melalui analisis laporan keuangan yang membandingkan angka-angka dalam laporan keuangan di periode tertentu dengan periode 
sebelumnya. Menganalisis laporan keuangan dengan pengukuran rasio keuangan dibagi menjadi empat jenis yaitu rasio profitabilitas, rasio likuiditas, rasio solvabilitas dan rasio aktivitas. Dari berbagai jenis rasio yang paling sering digunakan adalah rasio profitabilitas karena bisa menunjukan kemampuan perusahaan dalam menghasilkan keuntungan, salah satu pengukurannya yaitu Return On Assets (ROA) yang dimana dengan pengukuran ini bisa menunjukan kemampuan perusahaan dalam menghasilkan keuntungan dari aktiva yang dimilikinya (Harahap, 2016). Semakin tinggi nilai ROA suatu bank maka itu menunjukan semakin baik kinerja keuangan bank tersebut dan begitupun sebaliknya jika semakin kecil nilai ROA suatu bank maka kinerja keuangan bank tersebut bisa dikatakan dalam keadaan yang buruk.

Tetapi dalam pengukurannya terdapat kekurangan yaitu tidak mengikutsertakan biaya modal dan bergantung pada metode yang digunakan dalam penyusunan laporan keuangan sehingga pengukuran ini seringkali tidak menunjukan keadaan perusahaan yang sesungguhnya. Hal ini menunjukan bahwa adanya kesenjangan antara teori dengan kenyataan yang terjadi, maka dari itu penggunaan pengukuran Economic Value Added (EVA) sebagai pelengkap karena EVA adalah indikator pengukuran nilai tambah ekonomis yang memperhitungkan biaya modal guna menciptakan nilai dari investasi, yang dihasilkan akibat dari strategi manajemen (Putri, 2018). Nilai EVA yang positif menandakan bahwa bank itu sudah berhasil menciptakan nilai tambah ekonomis yang artinya kinerja keuangan bank dalam kondisi yang baik, begitupun sebaliknya jika nilai EVA yang negatif di suatu bank menandakan bahwa bank itu belum berhasil menciptakan nilai tambah ekonomis yang artinya kinerja keuangan bank dalam kondisi yang buruk.

Kedua pengukuran tersebut memiliki kekurangan dan kelebihan yang berbeda, perbedaan inilah yang akan menghasilkan keputusan dalam memilih pengukuran mana yang akan digunakan untuk menilai kinerja keuangan bank dan juga bisa menunjukan pengukuran mana yang memberikan informasi secara lengkap untuk para penggunanya salah satunya untuk para investor agar bisa menentukan keputusan dalam berinvestasi.

Hal ini pernah diteliti sebelumnya oleh (Saragih, 2011) yang menguji perbandingan Capital Adequancy Ratio (CAR), Return On Assets (ROA), dan Loan Deposit Ratio (LDR) pada bank konvensional dan bank syariah. Hasil dari penelitiannya yaitu tidak terdapat perbedaan yang signifikan antara variabel CAR, ROA dan LDR pada bank syariah dan bank konvensional, kinerja keuangan pada bank syariah dinilai lebih baik dari kinerja keuangan pada bank konvensional. Dalam penelitian lain yang dilakukan oleh (Septiyaningrum, 2018) yang menguji perbandingan variabel Return On Assets (ROA) dan Economic Value Added (EVA) pada PT. Bank Tabungan Negara Tbk. Hasil penelitiannya yaitu terdapat perbedaan yang signifikan dari kedua pengukuran tersebut dengan pengukuran ROA yang dinilai lebih baik dalam mengukur kinerja keuangan pada bank tersebut.

Dilatarbelakangi oleh hal-hal yang sudah diuraikan diatas, karena berdasarkan penelitianpenelitian sebelumnya yang masih ada perbedaan dari hasil yang terkait dan adanya kesenjangan antara teori dengan kenyataan yang terjadi. Maka hal inilah yang mendorong peneliti untuk melakukan penelitian lebih lanjut mengenai perbandingan kedua metode tersebut dengan judul "Analisis Perbandingan Return On Asset dan Economic Value Added pada Bank Konvensional dan Bank Syariah periode 2015 - 2019"

\section{METODE PENELITIAN}

Metode penelitian yang digunakan adalah metode analisis komparatif, yaitu analisis yang membandingkan antara satu variabel atau lebih dari kelompok sampel yang berbeda, yang hasilnya 
akan menunjukan apakah terdapat perbedaan yang signifikan atau hanya terjadi karena kebetulan antar variabel tersebut (Anwar, 2013). Penelitian ini akan membandingkan kinerja keuangan bank dengan pengukuran Return On Assets dan Economic Value Added pada bank konvensional dan bank syariah. Jenis pendekatan yang digunakan adalah deskripsi kuantitatif, yaitu penelitian yang bertujuan untuk membuat deskripsi secara sistematis, akurat, sesuai dengan fakta dan data yang ada. Data yang digunakan adalah data sekunder yang diperoleh menggunakan metode dokumentasi dari internet melalui situs resmi bank dalam bentuk annual report selama periode 2015 - 2019.

Populasi dari penelitian ini adalah Bank Umum Konvensional dan Bank Umum Syariah yang ada di Indonesia periode 2015 - 2019 dengan total 110 untuk bank umum konvensional dan 14 untuk bank umum syariah, sedangkan dalam menentukan sampelnya menggunakan metode purposive sampling, yaitu penentuan sampel berdasarkan kriteria tertentu. Dalam penelitian ini memiliki kriteria yaitu merupakan bank milik pemerintah yang mempublikasikan laporan keuangannya di periode 2015 - 2019 dan menggunakan sistem perbankan ganda. Maka sampel yang memenuhi kriteria tersebut adalah Bank Mandiri, Bank Rakyat Indonesia (BRI) dan Bank Negara Indonesia (BNI) yang mewakili bank umum konvensional. Sedangkan yang mewakili bank umum syariah adalah Bank Syariah Mandiri (BSM), Bank Rakyat Indonesia (BRI) Syariah dan Bank Negara Indonesia (BNI) Syariah.

Operasional variabel yaitu suatu pernyataan terkait variabel yang ditetapkan untuk ditarik kesimpulan, dalam penelitian ini ada dua variabel yang akan dibandingkan yaitu ROA dan EVA.

Return On Assets adalah rasio pengukuran yang digunakan untuk mengukur laba atau keuntungan yang di peroleh dari penggunaan aktivanya. (Jalil, 2020).

$$
\text { ROA }=\frac{\text { Laba bersih setelah pajak }}{\text { Total aktiva }} \times 100 \%
$$

Economic Value Added adalah indikator untuk melihat adanya penciptaan nilai dari suatu investasi. (Silvia, 2020)

$E V A=$ NOPAT - CC

Perhitungan Net Operating Profit After Tax (NOPAT)

NOPAT $=$ Laba bersih setelah pajak + Beban bunga

Perhitungan Capital Charger (CC)

$$
C C=\text { WACC } x I C \text {. }
$$

Perhitungan Weighted Avarage Cost of Capital (WACC)

$$
W A C C=[(D \times r d)(1-\text { tax })+(\text { Exre })] \times 100 \%
$$

Tingkat Hutang $(D)=\frac{\text { Total liabilitas }+ \text { Dana syirkah }}{\text { Total passiva }} \times 100 \%$

Cost of Debt $(r d)=\frac{\text { Beban bunga }}{\text { Total liabilitas }+ \text { Dana syirkah }} \times 100 \%$

Tingkat Pajak $($ Tax $)=\frac{\text { Beban pajak }}{\text { Laba bersih sebelum pajak }} \times 100 \%$

Tingkat Modal $(E)=\frac{\text { Total ekuitas }}{\text { Total passiva }} \times 100 \%$

Cost of Equity $(\mathrm{re})=\frac{\text { Laba bersih setelah pajak }}{\text { Total ekuitas }} \times 100 \%$

Perhitungan Invested Capital (IC)

$I C=$ Total liabilitas + Dana syirkah + Total ekuitas - Liabilitas jangka pendek

Analisis Perbandingan Return On Asset dan Economic Value Added Pada Bank Konvensional dan Bank Syariah Delia Arsita dan Nana Diana 
Pengolahan datanya menggunakan aplikasi SPSS versi 2.1 dengan menguji data melalui Uji Normalitas dengan pendekatan Kolmogorov-Smirnov, yaitu uji prasyarat mengenai kelayakan sebuah data penelitian untuk dianalisis. Dari hasil uji tersebut jika nilai sig. $>0,05$ maka data tersebut berdistribusi normal lalu akan dilanjutkan ke statistik Parametic dan jika nilai sig. $<0,05$ maka data tersebut tidak berdistribusi normal lalu akan dilanjutkan ke statistik Nonparametic.

Selanjutnya uji perbandingan dua kelompok sampel data sesuai dengan hasil uji normalitas, jika data berdistribusi normal maka bisa menggunakan statistik parametic yaitu Uji Independen Sample T-Test dan jika data tidak berdistribusi normal maka bisa menggunakan statistik nonparametic yaitu Uji Mann-Whitney Test. Kedua uji tersebut digunakan untuk membandingkan sampel data dengan dua variabel yang bersifat bebas atau independen.

Tujuan dari adanya uji perbandingan yaitu untuk menolak atau menerima hipotesis yang telah dibuat. Kriteria pengujian hipotesis yaitu Ho diterima dan Ha ditolak jika nilai sig. $<0.05$, Ho ditolak dan Ha diterima jika nilai sig. $>0.05$. Formula pengujian hipotesis : Ho : Adanya perbedaan kinerja keuangan bank yang signifikan pada bank umum konvensional dan bank umum syariah $\mathrm{Ha}$ : Tidak adanya perbedaan kinerja keuangan bank yang signifikan pada bank umum konvensional dan bank umum syariah.

\section{HASIL DAN PEMBAHASAN}

Analisis kinerja keuangan yaitu analisis yang diukur untuk melihat kondisi keuangan sebuah perusahaan di periode tertentu dan periode sebelumnya agar mengetahui bagaimana perkembangan pada perusahaan setiap tahunnya. Semakin bagus kinerja keuangan sebuah perusahaan maka semakin banyak pula investor yang akan melirik untuk menanamkan modal nya di perusahaan tersebut, begitupun sebaliknya jika kinerja keuangan perusahaan menurun maka para investor tidak mau menanamkan modal di perusahaan tersebut karena tidak mau menanggung resiko kedepannya.

Tabel 1.

\section{Hasil Perhitungan ROA}

\begin{tabular}{lccccc}
\hline \multirow{2}{*}{ Nama Bank } & \multicolumn{5}{c}{ ROA (\%) } \\
\cline { 2 - 5 } & $\mathbf{2 0 1 5}$ & $\mathbf{2 0 1 6}$ & $\mathbf{2 0 1 7}$ & $\mathbf{2 0 1 8}$ & $\mathbf{2 0 1 9}$ \\
\hline Bank Mandiri & 2,49 & 1,42 & 2,05 & 2,32 & 1,78 \\
\hline BRI & 2,98 & 2,67 & 2,64 & 2,57 & 2,53 \\
\hline BNI & 1,80 & 1,91 & 1,97 & 1,92 & 1,87 \\
\hline BSM & 0,41 & 0,41 & 0,42 & 0,62 & 1,14 \\
\hline BRI Syariah & 0,51 & 0,61 & 0,32 & 0,28 & 0,17 \\
\hline BNI Syariah & 0,99 & 0,98 & 0,88 & 1,01 & 1,21 \\
\hline
\end{tabular}

Sumber : Hasil data diolah SPSS, 2020

Bank konvensional dan bank syariah dari tahun ketahun nilai ROA nya menunjukan pergerakan yang berfluktuasi. Rata-rata nilai ROA pada bank konvensional mempunyai nilai $>1,5 \%$ yang bisa dikatakan kinerja keuangan bank konvensional nya dalam kondisi yang baik, yang artinya bank konvensional ini bisa menghasilkan keuntungan dari pengelolaan aktiva yang dimiliki bank nya masing-masing. Tetapi pada waktu tertentu penurunan pun terjadi, ini bisa disebabkan oleh faktor seperti adanya ketidakstabilan dalam perekonomian di Indonesia salah satunya yaitu dampak dari perang dagang di tahun 2018 itu sangat mempengaruhi kinerja keuangan pada bank konvensional. Kondisi BRI dan BNI dari tahun 2018 sampai tahun 2019 mengalami penurunan nilai ROA nya 
sedangkan Bank Mandiri mengalami penurunannya di tahun 2019, yang artinya bank tersebut belum bisa bertahan dalam persaingan bisnis yang ketat pada saat itu.

Untuk rata-rata nilai ROA pada bank umum syariah mempunyai nilai $<1,5 \%$ yang bisa dikatakan kinerja keuangan bank syariah nya dalam kondisi yang cukup baik dan pergerakannya yang stabil itu menunjukan bahwa adanya perkembangan yang baik pada bank syariah di Indonesia. Ketidakstabilan yang terjadi di tahun 2018 juga mempengaruhi bank syariah, dimana BRI Syariah itu belum bisa bertahan karena ditahun 2018 sampai tahun 2019 nilai ROA nya mengalami penurunan yang cukup signifikan, tapi lain halnya dengan BSM dan BNI Syariah ditahun tersebut pergerakan nilai ROA itu tetap meningkat artinya bank tersebut bisa bertahan dalam persaingan bisnis pada saat itu.

Jika dibandingkan kinerja keuangan dengan pengukuran ROA di bank konvensional yang lebih baik adalah BNI karena pergerakannya yang stabil dan ketika penurunan pun nilainya tidak terlalu signifikan, sedangkan di bank syariah yang lebih baik adalah BSM karena peningkatannya yang cukup signifikan dari tahun ketahun. Hasil pengukuran ROA dari kedua sistem perbankan yang lebih baik adalah bank syariah walaupun nilai yang diperoleh nya kecil tetapi tetap stabil dalam pergerakannya ketika ada penurunan pun tidak terlalu signifikan dan bank syariah ini mampu bertahan dalam persaingan bisnis yang ketat. Selain pengukuran Return On Assets ada metode pengukuran lain juga yang bisa menilai kinerja keuangan bank yaitu pengukuran Economic Value Added (EVA).

Tabel 2.

Hasil Perhitungan EVA

\begin{tabular}{llllrr}
\hline \multirow{2}{*}{ Nama Bank } & \multicolumn{5}{c}{ EVA (Jutaan) } \\
\cline { 2 - 6 } Bank Mandiri & $\mathbf{2 0 1 5}$ & $\mathbf{2 0 1 6}$ & $\mathbf{2 0 1 7}$ & $\mathbf{2 0 1 8}$ & $\mathbf{2 0 1 9}$ \\
\hline BRI & 4.554 .016 & 4.465 .254 & 4.518 .874 & 5.276 .808 & 5.951 .256 \\
\hline BNI & 5.934 .375 & 6.488 .392 & 6.357 .200 & 7.386 .180 & 8.051 .321 \\
\hline BSM & 2.237 .879 & 2.762 .491 & 3.273 .254 & 4.429 .131 & 4.430 .315 \\
\hline BRI Syariah & 599.677 & 628.739 & 678.804 & 707.164 & 803.831 \\
\hline BNI Syariah & 287.164 & 302.468 & 399.039 & 395.909 & 488.419 \\
\hline
\end{tabular}

Sumber : Hasil data diolah SPSS, 2020

Bank konvensional dan bank syariah dari tahun ketahun nilai EVA nya menunjukan pergerakan yang berfluktuasi. Rata-rata nilai EVA pada bank konvensional menunjukan peningkatan yang cukup signifikan dengan nilai yang besar dan juga positif yang artinya bank tersebut sudah berhasil menciptakan nilai tambah ekonomi bagi perusahaan, hal ini membuktikan bahwa kinerja keuangan pada bank tersebut dalam kondisi yang baik. Tetapi pada waktu tertentu nilai EVA pada bank tersebut ada yang mengalami penurunan juga, seperti yang terjadi pada Bank Mandiri yang mengalami penurunan di tahun 2016 dan BRI yang mengalami penurunan di tahun 2017. Penurunan tersebut bisa disebabkan oleh banyak faktor, salah satunya karena adanya ketidakstabilan dalam dunia perbankan pada saat itu.

Rata-rata nilai EVA pada bank umum syariah mempunyai nilai yang besar dan juga positif, pergerakan setiap tahunnya pun selalu meningkat dengan nilai yang cukup signifikan. Ketidakstabilan yang terjadi di tahun 2018 juga mempengaruhi bank syariah, yang dimana BRI Syariah mengalami penurunan nilai EVA di tahun tersebut. Tapi lain halnya dengan BSM dan BNI Syariah ditahun tersebut pergerakan nilai EVA nya tetap meningkat artinya bank tersebut mampu menciptakan nilai tambah ekonomi setiap tahunnya dan mampu bertahan dalam persaingan bisnis pada saat itu. 
Jika dibandingkan kinerja keuangan dengan metode EVA di bank konvensional yang lebih baik adalah BNI karena selalu meningkat dengan nilai yang besar dan positif, sedangkan di bank syariah yang lebih baik adalah BSM karena menghasilkan nilai yang selalu meningkat. Hasil pengukuran EVA dari kedua sistem perbankan yang lebih baik adalah bank syariah karena selalu mengalami peningkatan dengan nilai yang besar dan positif walaupun terjadi penurunan tetapi tidak terlalu signifikan jika dibandingkan dengan penurunan yang terjadi pada bank konvensional, yang bisa diartikan bahwa bank syariah sudah berhasil menciptakan nilai tambah ekonomi bagi bank itu sendiri dan bank syariah menunjukan bahwa kinerja keuangannya dalam keadaan yang baik.

Dari kedua pengukuran kinerja keuangan bank, yang memberikan hasil lebih baik adalah pengukuran dengan EVA karena pengukuran ini bisa mengukur kinerja keuangan yang memperhatikan resiko pada bank dengan memperhitungkan biaya modal. Pengukuran ini juga bisa mencerminkan nilai perusahaan yang sesungguhnya dan memberikan informasi keuangan yang lebih detail, maka pengukuran ini di nilai lebih baik dalam mengukur kinerja keuangan bank dibandingkan ROA. Hasil penelitian ini sesuai dengan penelitian sebelumnya yang dilakukan (Putri, 2018) yang menguji kedua variabel tersebut dan hasil penelitiannya menyatakan bahwa pengukuran dengan Economic Value Added lebih baik dari pada pengukuran dengan Return On Asset.

Tabel 3.

Hasil Uji Normalitas

\begin{tabular}{llrr}
\hline \multicolumn{1}{c}{$\mathrm{N}$} & & ROA & EVA \\
\hline \multirow{2}{*}{ Normal Parameters $^{\mathrm{a}, \mathrm{b}}$} & & 30 & 30 \\
\hline \multirow{2}{*}{ Most Extreme Differences } & Mean & 1.4293 & 2753941.80 \\
\cline { 2 - 4 } & Std. Deviation & .86811 & 2625643.196 \\
\hline & Absolute & .124 & .271 \\
\cline { 2 - 4 } & Positive & .124 & .271 \\
\cline { 2 - 4 } Kolmogorov-Smirnov Z & Negative & .124 & .167 \\
\hline Asymp. Sig. (2-tailed) & & .681 & .485 \\
\hline
\end{tabular}

Sumber : Hasil data diolah SPSS, 2020

Uji Normalitas dengan pendekatan Kolmogorov-Smirnov Test menunjukan bahwa data berdistribusi normal karena nilai signifikasi dari pengukuran ROA pada bank konvensional dan bank syariah adalah 0,742 yang artinya sudah melebihi persyaratan (sig. > 0,05), tetapi pada pengukuran EVA nya menghasilkan data tidak berdistribusi normal karena nilai signifikasi dibawah persyaratan (sig. > 0,05) yaitu 0,024. Maka secara keseluruhan data dalam penelitian ini dinyatakan tidak berdistribusi normal karena ada salah satu variabel yang menunjukan hasilnya tidak berdistribusi normal dan selanjutnya dalam menguji hipotesis akan menggunakan statistik nonparametic.

Penggunaan metode statistik nonparametic yaitu untuk penelitian yang data nya tidak berdistribusi normal atau sampel data yang digunakan terlalu sedikit maka diperlukan alternatif lain untuk mengujinya seperti Uji Mann-Whitney Test. Uji Mann-Whitney Test yang bertujuan untuk membandingkan dua variabel yang bebas atau idependen, uji ini biasanya digunakan untuk data yang tidak berdistribusi normal atau jumlah sampel penelitiannya kurang dari 30 .

Tabel 4.

Hasil uji Mann-Whitney Test (ROA dan EVA)

Kinerja Keuangan

Analisis Perbandingan Return On Asset dan Economic Value Added Pada Bank Konvensional dan Bank Syariah Delia Arsita dan Nana Diana 


\begin{tabular}{lr}
\hline Mann-Whitney U & .000 \\
\hline Wilcoxon W & 465.000 \\
\hline Z & -6.653 \\
\hline Asymp. Sig. (2-tailed) & .000
\end{tabular}

Sumber : Hasil data diolah SPSS, 2020

Menguji hipotesis terkait perbandingan antara penilaian kinerja keuangan menggunakan pengukuran ROA dan EVA menghasilkan nilai signifikasi 0,000 < 0,05 sehingga Ho diterima dan Ha ditolak, yang artinya penilaian kinerja keuangan menggunakan pengukuran ROA dan EVA terdapat perbedaan yang signifikan.

Tabel 5.

Hasil uji Mann-Whitney Test (ROA)

\begin{tabular}{lr}
\hline & ROA \\
\hline Mann-Whitney U & .000 \\
\hline Wilcoxon W & 120.000 \\
\hline Z & -4.667 \\
\hline Asymp. Sig. (2-tailed) & .000 \\
\hline Exact Sig. [2*(1-tailed Sig.)] & $.000^{\mathrm{b}}$ \\
\hline
\end{tabular}

Sumber: Hasil data diolah SPSS, 2020

Menguji hipotesis terkait perbandingan antara penilaian kinerja keuangan menggunakan pengukuran ROA pada bank konvensional dan bank syariah menghasilkan nilai signifikasi $0,000<$ 0,05 sehingga Ho diterima dan Ha ditolak, yang artinya penilaian kinerja keuangan menggunakan pengukuran ROA pada bank konvensional dan bank syariah terdapat perbedaan yang signifikan.

Tabel 6.

Hasil uji Mann-Whitney Test (EVA)

\begin{tabular}{lr}
\hline & EVA \\
\hline Mann-Whitney U & .000 \\
\hline Wilcoxon W & 120.000 \\
\hline Z & -4.666 \\
\hline Asymp. Sig. (2-tailed) & .000 \\
\hline Exact Sig. [2*(1-tailed Sig.)] & $.000^{\mathrm{b}}$ \\
\hline her : Hasil data diolah SPSS, 2020
\end{tabular}

Menguji hipotesis terkait perbandingan antara penilaian kinerja keuangan menggunakan pengukuran EVA pada bank konvensional dan bank syariah menghasilkan nilai signifikasi $0,000<$ 0,05 sehingga Ho diterima dan Ha ditolak, yang artinya penilaian kinerja keuangan menggunakan pengukuran EVA pada bank konvensional dan bank syariah terdapat perbedaan yang signifikan.

Hasil dari penelitian tersebut sesuai dengan penelitian yang dilakukan (Septiyaningrum, 2018) yang menguji perbandingan variabel Return On Assets (ROA) dan Economic Value Added (EVA) pada PT. Bank Tabungan Negara Tbk. Hasil penelitiannya yaitu terdapat perbedaan yang signifikan dari kedua pengukuran tersebut. Dan didukung juga oleh penelitian (Naili, 2013) yang menguji Rasio keuangan dan Economic Value Added (EVA) pada bank syariah dan bank konvensional. Hasil penelitiannya yaitu terdapat perbedaan yang signifikan dari kedua pengukuran tersebut.

Bank konvensional dan bank syariah itu memiliki sistem penyusunan laporan keuangan yang berbeda, bank konvensional mengambil keuntungannya melalui beban bunga yang sudah di Analisis Perbandingan Return On Asset dan Economic Value Added Pada Bank Konvensional dan Bank Syariah 
tetapkan sebelumnya dengan persentase tertentu. Sedangkan bank syariah melalui sistem bagi hasil yang dimana sistem ini mengusahakan agar tidak adanya pihak yang merasa dirugikan. Tetapi dalam pengukuran kinerja keuangannya antara kedua jenis bank tersebut itu hampir sama, nilai yang dihasilkan untuk rasio keuangan itu menunjukan bahwa persaingan bisnis antara kedua jenis bank tersebut sangatlah ketat maka dari itu masing-masing bank harus mampu meningkatkan kinerja keuangannya agar bisa tetap bertahan dan mampu bersaing.

Pengukuran kinerja keuangan pada bank konvensional dan bank syariah menunjukan bahwa kedua jenis bank tersebut mampu mengembangkan usahanya dan mampu mempertahankan kinerja nya dalam kondisi perekonomian Indonesia yang tidak stabil pada periode tersebut, perbedaan dalam pengukuran ini juga bisa dijadikan pertimbangan para manager agar lebih memperhatikan setiap bagian yang ada dalam laporan keuangan untuk ditingkatkan kembali dan para investor pun bisa mendapatkan informasi yang lebih detail mengenai keuangaan di suatu bank agar bisa memutuskan keputusan yang tepat dalam berinvestasi serta mendapatkan keuntungan yang sesuai dengan harapan. Dalam penelitian ini hanya menggunakan data sekunder yang diperoleh dari situs resmi masing-masing bank milik pemerintah yang dijadikan sampel dan metode pengukuran yang dibandingkan hanya Return On Assets dan Economic Value Added.

\section{SIMPULAN DAN SARAN}

Dari hasil penelitian ini bisa ditarik kesimpulan bahwa adanya perbedaan yang signifikan dalam penilaian kinerja keuangan dengan pengukuran ROA dan EVA pada bank konvensional dan bank syariah. Bank syariah dinilai lebih baik kinerja keuangannya berdasarkan pengukuran ROA dan berdasarkan pengukuran EVA. Dari data sampel yang digunakan, Bank Syariah Mandiri memiliki kinerja keuangan yang baik berdasarkan pengukuran ROA maupun pengukuran EVA di periode 2015 - 2019. Pengukuran kinerja keuangan bank yang baik tidak selalu dinilai dari hasil yang besar melainkan dari pergerakan setiap tahunnya dan mampu memberikan informasi yang menyuluruh serta akurat kepada pihak yang membutuhkan informasi tersebut, jika ingin menilai kinerja keuangan bank maka disarankan untuk menggunakan pengukuran EVA karena pengukuran ini bisa mengukur kinerja keuangan yang bisa memperhatikan resiko pada bank dengan memperhitungkan biaya modal dan dapat mencerminkan nilai perusahaan yang sesungguhnya.

Bagi manager pada bank tersebut diharapkan lebih memperhatikan setiap bagian yang ada dalam laporan keuangan untuk ditingkatkan kembali agar kinerja keuangan bank nya menunjukan kondisi yang baik dan juga bisa menarik para investor untuk menanamkan modalnya di bank tersebut. Bagi para investor yang ingin berinvestasi di sarankan untuk mempertimbangkan pengukuran kinerja keuangan lainnya agar bisa mengambil keputusan yang baik dan bisa meminimalisir resiko di masa yang akan datang. Dalam penelitian ini sampel dan metode yang digunakan lebih sedikit, di sarankan untuk penelitian selanjutnya agar menambahkan sampel, memperluas periode penelitian dan juga menambahkan pengukuran yang lainnya agar bisa mendapatkan hasil yang lebih akurat.

\section{REFERENSI}

Anwar, A. (2009). Statistika untuk Penelitian dan aplikasinya SPSS dan EXCEL. Kediri: IAIT Press.

Harahap, S. D. (2016). "Analisis perbandingan Kinerja Keuangan Bank Umum Syariah dengan menggunakan Rasio Keuangan dan Economic Value Added periode 2010-2015." (Skripsi). Jakarta : Universitas Islam Negeri Syarif Hidayatullah.

Ismail. (2014). Akuntansi Bank Teori dan Aplikasi dalam Rupiah. Jakarta: Prenadameda Group. 
Jalil, M. (2020). Pengaruh EPS, ROA, DER dan CR terhadap Harga Saham pada perusahaan makanan dan minuman yang terdaftar di BEI. Akuntansi Dan Keuangan, 9(1), 60-70.

Muchlish, A., \& Umardani, D. (2016). Analisis perbandingan keuangan Bank Syariah dan Bank Konvensional Di Indonesia. Jurnal Manajemen Dan Pemasaran Jasa, 9(1), 129-156.

Naili, N. (2013). Analisis Perbandingan Kinerja Keuangan Perbankan Syariah dengan Perbankan Konvensional. Semarang : Universitas Dian Nuswantoro.

Nurmal M., U. R. (2018). "Analisis Perbandingan Kinerja Bank Syariah dan Bank Konvensional di Indonesia." (Skripsi) Yogyakarta : Universitas Islam Indonesia.

Putri, A. A. (2018). Perbandingan Kinerja Keuangan Perusahaan berdasarkan Return On Assets (ROA) dengan Economic Value Added (EVA). Jurnal Ekobis Dewantara, 1(10), 37-44.

Saragih, A. F. (2011). Analisis Perbandingan Kinerja Keuangan antara Bank Syariah dan Bank Konvensional.

Septiyaningrum, F. D. (2018). Analisis Perbandingan antara Return On Assets (ROA) dengan Economic Value Added (EVA) dalam menilai kinerja perusahaan pada PT. Bank Tabungan Negara (Persero) Tbk, 1-16.

Silvia, D. (2020). Analisa Perbandingan Economic Value Added (Eva) Dan Return On Asset (Roa) Dalam Menilai Kinerja Perusahaan. Jurnal Akuntansi Dan Keuangan, 11(1), 1-17.

Sujarweni, V. W. (2016). Kupas Tuntas Penelitian Akuntansi dengan SPSS. Yogyakarta: Pustaka Baru.

Sulistiyo, H. dkk. (2020). Teknik Menelusuri dan Memahami Artikel Ilmiah di Jurnal Nasional dan Internasional. Yogyakarta: CV. Absolute Media.

Syamsiah. (2015). "Analisis Perbandingan Kinerja Keuangan Bank Konvensional Dengan Bank Syariah." (Skripsi) Makassar : Universitas Islam Negeri Alauddin Makassar. https://doi.org/10.37932/ja.v8i2.68

Wijaya, J. (2018). "Analisis Perbandingan Kinerja Keuangan dengan menggunakan Metode RGEC sebelum dan sesudah Go Public." (Skripsi) Lampung : Universitas Islam Negeri Raden Intan Lampung.

www.bni.co.id (28 Desember 2020, 16:08)

www.bnisyariah.co.id (28 Desember 2020, 15:27)

www.bri.co.id (28 Desember 2020, 12:08)

www.brisyariah.co.id (28 Desember 2020,11.34)

www.cnbcindonesia.com (28 Desember 2020, 20.00)

www.mandiri.co.id (28 Desember 2020, 13:10)

www.mandirisyariah.co.id (28 Desember 2020, 14.02) 